\title{
Andrei Ershov and the Soviet Information Age
}

\author{
GREGORY AfINOGENOV
}

I'm not original. My ideal is the creative mind, or, in terms of mottoes: IBM's "Think" and the poetic "never a day without a line."

-A. P. Ershov

When Mikhail Gorbachev came to power in 1985, the Soviet Union was suddenly confronted with two major, imminent transformations. The first was the restructuring and liberalization of Soviet society under the banner of glasnost' and free market reform, the subject of the most influential studies of the late Soviet era, which depict the break of the early perestroika years primarily in ideological or personal terms. ${ }^{1}$ The second, in a longer timeframe, was the arrival of the post-Fordist information economy, heralded in part by the worldwide explosion in personal computing over the course of the decade. Although it has received little attention, the plan to modernize and retool the Soviet economy using advanced scientific and technological means was integral to Gorbachev's promise. If the Soviet Union was to present an effective counterpart to the "capitalism of the age of electronics and informatics, of computers and robots"-as he put it in his address to the 27th Party Congress-it needed to turn the "acceleration of scientifictechnical progress" to its advantage, making the most of the "transformation

I would like to thank Loren Graham, Terry Martin, Rachel Koroloff, and Kritika's anonymous reviewers for their comments on previous versions of this essay.

1 See Alexei Yurchak, Everything Was Forever, Until It Was No More: The Last Soviet Generation (Princeton, NJ: Princeton University Press, 2005); Stephen Kotkin, Armageddon Averted (Oxford: Oxford University Press, 2003); and Archie Brown, The Gorbachev Factor (Oxford: Oxford University Press, 1996); but compare Jerry Hough, Democratization and Revolution in the USSR, 1985-1991 (Washington, DC: Brookings Institution Press, 1997), 22-60. 
of consciousness" and the "new psychology" it would bring. ${ }^{2}$ This approach implied a number of concrete tasks, among which "securing the computer literacy of students" was "especially urgent."3 In fact, Gorbachev had pushed through a mass computer literacy campaign in 1985, even before the death of Chernenko.

Andrei Petrovich Ershov, a 53-year-old academician and computer programmer, took command of the project from the very beginning. $\mathrm{He}$ was already known throughout the programming community on both sides of the Iron Curtain for his visionary views on the transformative power of mass computing, and he had risen to prominence in the Academy of Sciences partly as a result of his international network of contacts. In the party journal Kommunist, Ershov made a powerful case for the centrality of "informatization" to the perestroika project: the expansion of personal computing, guided and pushed forward by the Soviet educational system, promised not only the "democratization of the information structure of society" but a dramatic society-wide shift toward private initiative at the expense of bureaucracy. Ershov thus proposed a single solution to the twin challenges of the 1980 s. Universal computer literacy was to be a worthy successor to the grandest of Soviet enterprises-electrification, collectivization, and industrialization. ${ }^{4}$

By the time the Soviet Union ceased to exist in 1991, the computer literacy campaign had collapsed utterly, squandering widespread initial interest in the subject. Today, the millions of students who once used Ershov's textbooks remember it as a late Soviet absurdity. How did this gifted programmer, whose writings on computer literacy had been widely publicized at home and abroad, fail so completely at turning his ideas into reality? It was not, I argue, merely the unpropitious conditions of an imploding system that led to the reform's collapse. Its origins lay instead in a persistent set of ideals formulated within the post-Stalin scientific community and rearticulated through contemporary debates on cybernetics and the correspondence networks of international computer science. These ideals provided confident, affirmative answers to questions that had become unusually potent as the postwar years made science more massive, popular, and public, in the Soviet Union as well as elsewhere: Could scientific life provide a blueprint for human flourishing? Could science be made to serve moral and social, as well

${ }^{2}$ M. S. Gorbachev, "Politicheskii doklad Tsentral'nogo komiteta KPSS XXVII s"ezdu," in Izbrannye rechi $i$ stat ' $i$ (Moscow: Politizdat, 1987), 3:180-286. All translations mine except where noted.

3 Ibid., 229.

4 A. P. Ershov, "Informatizatsiia: Ot komp'iuternoi gramotnosti uchashchikhsia k informatsionnoi kul'ture obshchestva," in Izbrannye trudy (Novosibirsk: Nauka, 1994), $371-$ 84 (originally published in Kommunist 1988, no. 2). 
as technical, ends? Much of this heritage-the utopian appeal of science in the public imagination-was shared by the Gorbachev project more broadly; after all, "the acceleration of scientific-technical progress" had been one of the cardinal slogans of the 22nd Party Congress of 1961, long before Gorbachev made uskorenie a keystone of perestroika. ${ }^{5}$ Ershov's career as a scientific reformer offers us an alternate vision of a perestroika based on scientific and technological transformation-and explains why such visions nevertheless left the Soviet Union unprepared for the information age.

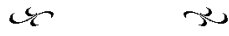

Like Gorbachev, Ershov began his career during the years immediately surrounding the death of Stalin. As a student, Ershov had initially planned on becoming a physicist, but Stalin-era restrictions forced him to turn to mathematics instead. He graduated from Moscow State University's Department of Computational Mathematics in 1954, among the first classes to receive a degree in programming. For the next three years, he worked as a graduate student under Aleksei Liapunov—a leading Soviet mathematician and a prominent figure in the emerging field of cybernetics-before being assigned to head his own laboratory in Novosibirsk's "Akademgorodok," then still under construction. ${ }^{6} \mathrm{He}$ was thus, at the age of 28 , already on his way to becoming a full-fledged member of the Soviet scientific establishment.

In the postwar era, this career path had great potential. Recent scholarship on the history of Soviet science has shown how the Cold War allowed scientists to accumulate tremendous social and institutional power, especially in the upper tiers of the Academy of Sciences hierarchy; Akademgorodok itself was a massive monument to the state's commitment to supporting both basic and applied research. Individual scientists could often influence government policy and even foreign relations. Matthew Evangelista's Unarmed Forces, to take only one example, demonstrates the ability of highly placed scientists such as Evgenii Velikhov to translate their authority as scientists into substantive political change-in Velikhov's case, the struggle against nuclear weapons.

\footnotetext{
${ }^{5}$ XXII s"ezd Kommunisticheskoi partii Sovetskogo Soiuza: Stenograficheskii otchet (Moscow: Politizdat, 1962), 282.

6 See Irina Kraineva, "Nauchnaia biografiia A. P. Ershova" (Candidate's diss., Tomsk University, 2008). The definitive study of Akademgorodok is Paul Josephson, New Atlantis Revisited: Akademgorodok, the Siberian City of Science (Princeton, NJ: Princeton University Press, 1997).

7 Matthew Evangelista, Unarmed Forces: The Transnational Movement to End the Cold War (Ithaca, NY: Cornell University Press, 1999); Nikolai Krementsov, Stalinist Science (Princeton, NJ: Princeton University Press, 1997); David Holloway, Stalin and the Bomb (New Haven:
} 
Several decades later, in attempting to translate his educational ideas into reality, Ershov would benefit from the same effect.

Developing as a scientist in the 1950 s also meant participating in a vibrant and burgeoning new scientific culture, shaped by cybernetics and computer technology and confident in the ability of the exact sciences, given sufficient energy and devotion, to effect personal, aesthetic, and social change. ${ }^{8}$ As in the prewar world of amateur rocket enthusiasts described by Asif Siddiqi in The Red Rockets' Glare, this fascination with the possibilities of science spilled over into popular culture, creating a rush of widely read science fiction novels, popularscientific periodicals, and other media. One of the best-known products of this vogue, Arkadii and Boris Strugatskii's gently satirical Monday Begins on Saturday, is set in a research institute populated by characters from Russian folklore and stars a computer programmer as its main character; the title refers unironically to the characters' 24/7 dedication to their work. ${ }^{9}$ As Benjamin Nathans has argued for Aleksandr $\mathrm{Vol}^{\prime}$ pin, immersion in this culture could mean taking it to its logical conclusion and using the "exact methods" of cybernetics as a blueprint for political engagement. ${ }^{10}$ Ershov never became a dissident—or, like Gorbachev, a political reformer-yet his experience during the Thaw shaped his confidence in the power of science and technology to transform society.

Ershov's early career formed his vision of an ideal working programmer: confident, independent, and consummately professional yet also endowed with a rigorous and methodical mind. As a young working scientist whose Monday really did begin on Saturday, he felt its influence professionally as well: he came to value a kind of heroic individualism and selfless dedication to science above all else. His diary, which he kept on a semicontinuous basis from 1958 to 1964 , records dramatic leadership conflicts with Liapunov and other colleagues in which personal and professional matters became hopelessly muddled. ${ }^{11}$ Personal life was seen to represent an impingement on professional

Yale University Press, 1994). See also Jeffrey Roberg, Soviet Science under Control (London: Macmillan, 1998).

${ }^{8}$ The most comprehensive study of the productive intersections among science, ideology, and Soviet life is still Loren Graham, Science, Technology, and Human Behavior in the Soviet Union (New York: Columbia University Press, 1987)

9 Asif Siddiqi, The Red Rockets' Glare (Cambridge: Cambridge University Press, 2010); Loren Graham, ed., Science and the Soviet Social Order (Cambridge, MA: Harvard University Press, 1990); Arkadii and Boris Strugatskii, Ponedel'nik nachinaetsia v subbotu (Moscow: Tekst, 1992 [1964]).

${ }^{10}$ Benjamin Nathans, "The Dictatorship of Reason: Aleksandr Vol'pin and the Idea of Rights under 'Developed Socialism," Slavic Review 66, 4 (2007): 630-63.

11 Arkhiv akademika A. P. Ershova (hereafter EA) f. 35, pp. 121, 124. (Here and below, all Ershov Archive materials are cited by folder and page number rather than URL; they are accessible from http://ershov.iis.nsk.su/archive/eaimage.asp.) 
responsibilities, leaving women particularly vulnerable to criticism. Ershov's recommendation letters from this period invariably value independence, initiative, and "goal-oriented ness" while less glowing recommendations carry notes like "because of a certain lack of activity, works best within a small group" and "she could benefit from more independence and energy ... [she] would work best as a coder in a two-person group with a stronger associate." 12 At one point, over the course of six months, Ershov logged a series of dry and rather negative conversations with a female subordinate about unfinished programming work, terminating simply with the line "Gave birth to a son!"13

It was around this time, too, that Ershov developed a set of obsessive notetaking and recording practices and began accumulating the nucleus of his massive personal archive, a preoccupation with organizing information that was reflected in similar demands he placed on his colleagues. They recalled that "[o]n every page-whether it was a draft of an article, a letter to a party organization, or a poem about his experiences on the road-there was always a record (instead of a page number) in the top corner: the date, the hour and minute, and place.... A few business trips with Ershov were enough to make this style of work, including both the absence of comfort and the accurate documentation of work materials, a conscious legacy." ${ }^{14}$ His first major project was rigorously mapped out in a series of brainstorming and project notebooks (the latter known collectively as the "Talmud"), to which every member of the team was expected to contribute. Reminders litter the pages: "This engaging chronicle [Letopis'] lacks synchroimpulses. Put down the date and hour with every new note. A. Ershov."15

One of the first entries in Ershov's diary records the visit of a group of American computer scientists to Moscow, where he was working as a graduate

12 EA f. 365 , pp. $1-48$.

13 EA f. 35, pp. 1-91.

${ }^{14}$ Iu. A. Pervin, "Ershov i Slovo," in Andrei Petrovich Ershov: Uchenyi i chelovek, ed. A. G. Marchuk (Novosibirsk: Rossiiskaia akademiia nauk, Sibirskoe otdelenie, 2006), 329-36. This edited volume is one of a number of primary and secondary works on Ershov produced under the aegis of his institute, which are valuable sources despite their tendency toward hagiography. Sce Kraineva, "Nauchnaia biografia"; I. V. Pottosin, ed., Novosibirskaia shkola programmirovania (pereklichka vremen) (Novosibirsk: Institut sistem informatiki imeni A. P. Ershova, 2004); Pottosin, ed., Stanovlenie Novosibirskoi shkoly programmirovaniia (mozaika vospominanii) (Novosibirsk: Institut sistem informatiki imeni A. P. Ershova, 2001); B. G. Mikhailenko, ed., Institut vychislitel'noi matematiki i matematicheskoi geofiziki (VTs) SO RAN: Stranitsy istorii (Novosibirsk: Geo, 2008).

15 A. P. Ershov, "Al'fa-rozhdenie,' ili kak sozdavalas' sistema avtomaticheskogo programmirovaniia," in A. P. Ershov: Uchenyi i chelovek, 17-31; I. V. Pottosin, "Istoriia Al'faproekta," in Stanovleniie Novosibirskoi shkoly programmirovaniia, 46-55; N. L. Cheremnykh, "Arkhiv akademika A. P. Ershova," in Novosibirskaia shkola programmirovaniia, 20-25; EA f. $19,22,23$. 
student at the Computing Center of the USSR Academy of Sciences. Prior to the visit, Ershov was skeptical that the encounter would be productive: "An interesting note in the Comm. of the ACM (no. 5. vol. 1, 1958) about the development of automatic programming at Remington Rand. As far as I could understand, it's the same thing [we're doing].... Already almost convinced: I won't hear any new ideas from the Americans." When the Americans did arrive, he found them "welcoming, friendly, and reasonably earnest. But it must be said that we had no 'acute' [politically sensitive] conversations." As they left, one of them, John W. Carr III, told Ershov to keep in touch, which left the Soviet programmer flattered and impressed. The parting was "very heartfelt." 16 For their part, Carr and his American colleagues noted "the continuing interest of the entire Soviet population in cybernetics" and predicted that " $[\mathrm{d}]$ espite a relative slow start, and mainly because of the flexibility of their mathematical leadership, Soviet use of computers may be expected to surpass in quality and quantity that of the United States." ${ }^{17}$

The visit also had a more concrete effect for Ershov: from conversations with the Americans, he learned about their work on achieving machine independence - that is, the development of programming languages not tied to a specific computer architecture. Out of this came an idea of a new machine-independent programming language, which was eventually adapted to the syntax of ALGOL (a new language developed in part by Alan Perlis, who was among the group of visiting Americans) and eventually called ALPHA. Ershov's work on the "ALPHA-translator"-a pathbreaking early optimizing compiler for the language-was the mainstay of his career for the next decade, especially after he definitively relocated to Akademgorodok. ${ }^{18}$ Ershov was thus indebted for his professional success not just to his role in an indigenous Soviet scientific community, but also to his contacts with a thennascent international one.

Ershov had consistently given credit for the "fermentation of ideas" about ALPHA to Western programmers through both the initial conversation with

\footnotetext{
16 EA f. 35, pp. 100-3. Emphasis in orig.

17 John W. Carr III et al., "A Visit to Computation Centers in the Soviet Union," Communications of the ACM 2, no. 6 (1959): 8-20.

18 Kraineva, "Nauchnaia biografiia," 53-60. For the early terminology of "automatic programming," see John Backus, "Programming in America in the 1950s-Some Personal Impressions," in A History of Computing in the Twentieth Century, ed. N. Metropolis et al. (New York: Academic Press, 1980), 125-35. A compiler, in contemporary usage, is a program that converts text written in a human-readable programming language into machine code that can be interpreted directly by a computer. An optimizing compiler is supposed to generate machine code that is more efficient (for instance, in memory or CPU usage) than the handcoded equivalent.
} 
the visiting Americans and other materials published abroad. After the meeting in 1958 , as he put it, the "research and projects of Soviet scientists became woven into the common fabric of the development of programming." 19 Unsurprisingly, his foreign contacts did not end there. As he moved upward on his career trajectory over the course of the 1960s and 1970s, he maintained a broad and extensive correspondence with computer scientists in America, Western Europe, and Japan and participated in a number of international organizations, such as the International Federation for Information Processing (IFIP) and the Association for Computing Machinery. These bodies, as well as the artificial intelligence (AI) researchers John McCarthy and Edward Feigenbaum (both frequent correspondents of Ershov's), have received considerable scholarly attention because of their ambivalent relationship to the Cold War. ${ }^{20}$ Paul Edwards's The Closed World, in particular, has singled out McCarthy and Feigenbaum's contributions to military-funded AI research. In Edwards's view, this branch of early computer culture played a fundamental role in the ideological construction of a self-enclosed, predictable, and rule-governed "closed world" which could be defended and controlled by planetary-scale, computerized military technologies - a vision that helped sell the American public on massive funding for computers as well as an expanding defense establishment. ${ }^{21}$

Even as both Soviet and American scientists made use of Cold War tensions to enhance their personal and professional authority, in their exchanges with one another they attempted to find ways of overcoming and circumventing geopolitical barriers in the service of a vaguely defined "common task of science," as Ershov put it in a letter to the Japanese computer scientist Hiroji Nishino. ${ }^{22}$ This meant, above all, demonstrating their mutual superiority over national or ideological narrow-mindedness. Just as the British computer scientist Richard Goodman congratulated him on the success of Gagarin's manned orbital flight, Ershov commiserated with his American colleagues

19 EA f. 23 , p. 150 ; f. 550 , p. 89.

20 On this correspondence in particular, see Ksenia Tatarchenko, "'Double Loyalties' in Counterpoint: Computer Science from Silicon Valley to the Golden Valley," in Trudy SORUCOM-2011, ed. A. N. Tomilin (Novgorod: Novgorodskii gosudarstvennyi universitet, 2011), 278-81. See also Tatarchenko, "Cold War Origins of the International Federation for Information Processing," IEEE Annals of the History of Computing 32, 2 (2010): 46-57, as well as the other articles in that issue.

21 Paul Edwards, The Closed World: Computers and the Politics of Discourse in Cold War America (Cambridge, MA: MIT Press, 1996). Peter Galison has argued that early cybernetics was shot through with images of a predictable, rational enemy drawn from the rhetoric of World War II ("The Ontology of the Enemy: Norbert Wiener and the Cybernetic Vision," Critical Inquiry 21, 1 [1994]: 228-66).

22 EA f. 128, p. 286, Ershov to Hiroji Nishino, 19 July 1973. 
after the assassination of John F. Kennedy. ${ }^{23}$ John McCarthy, not otherwise known for being a fellow-traveler, even entertained the idea-sincerely or not-that "Communism may well be a better system than capitalism, and the sooner it is achieved the sooner I will be able to see." 24 "It is indeed unfortunate that so much time is spent on emphasizing differences, and so little emphasizing similarities," wrote the computer scientist Peter Ingerman after Ershov expressed similar sentiments. "Perhaps someday all politicians will become statesmen and will recognize the commonality of human beings." 25

Citizenship in the international scientific community did not just involve assertions of commitment to transideological scientific ideals. It also meant being able to participate in creating, justifying, and maintaining long-lasting channels of information exchange against a charged political background. Often this was framed directly in terms that linked communication to computer science, as when Feigenbaum expressed a hope that "soon I will be able to dial your computer directly, perhaps even through satellite communication." "We seem to have established a communication channel which one all too rarely achieves in the world these days," wrote another correspondent. "Long may it remain open and noise free."

Although such metaphorical language was common, generally the significance of access to information was framed much more concretely. A majority of Ershov's incoming and outgoing foreign correspondence deals with requests for articles, books, and reprints or offers to establish more permanent exchange arrangements. For instance, in 1961 Ershov sent Carr a letter responding to his suggestion of "closer contacts" between Ershov's group and the journal Computing Reviews (which Carr edited). He suggested that their "unofficial cooperation" take the form of a regular exchange of abstracts, books, and conference proceedings dealing with compiler and

23 EA f. 135, p. 256, Richard Goodman to Ershov, 15 April 1961 (English in orig.); f. 125, p. 114, Ershov to Kazarinoff, 4 January 1964; f. 127, p. 95, Ershov to Paul Armer, 9 April 1968. See also, e.g., EA f. 127, p. 10, Ershov to Jacob Schwartz, 26 December 1968.

24 EA f. 133, p. 36, John McCarthy to Ershov, 15 October 1965 (English in orig.).

25 EA f. 131, p. 151, Peter Ingerman to Ershov, 9 May 1967. This form of "scientific internationalism" could intersect in uneasy ways with ideological questions. John Krige, American Hegemony and the Postwar Reconstruction of Science in Europe (Cambridge, MA: MIT Press, 2006), 153-90, demonstrates how a public dedication to openness and political impartiality provided justifications for excluding Soviet scientists, as avowedly partial, from the postwar scientific community. The Soviet insistence on compartmentalizing human-rights issues in an attempt to preserve scientific questions played a similar role. See also Paul Forman, "Scientific Internationalism and the Weimar Physicists," Isis 64, 2 (1973): 150-80.

26 EA f. 133, pp. 8-11, Feigenbaum to Ershov, 8 November 1965; f. 122, p. 174, M. M. Lehman to Ershov, 16 December 1977 (English in orig.). 
language development. ${ }^{27}$ When Peter Naur decided to cease publication of the ALGOL Bulletin -which kept the worldwide scientific community informed about work being done on the language-Ershov fired off a letter of protest, pointing out that "it played a major role for us, because only thanks to it could we, being located in the depths of Siberia, feel ourselves in the midst of the events surrounding ALGOL's development." 28 Just as his experiences in Akademgorodok led him to see the ideal scientist in terms of methodological and informational rigor, Ershov's international ties enmeshed him in a web of global information exchange defined through its universalistic commitment to science.

The link between these communities was realized concretely in the form of enormous amounts of foreign publications acquired with the help of Ershov's Western contacts. One list of such materials from a trip to the United States in 1970 covers 60 typewritten pages and includes nearly 500 items, from books and articles to advertisements and graduate-school bulletins. ${ }^{29} \mathrm{~A}$ brief 1983 "memo concerning the effectiveness of the international scientific contacts of Academy Corresponding Member A. P. Ershov" assessed the value of these links for Soviet computing in straightforward language:

The most direct indication of effectiveness is the material value of the scientific documentation received as a result of these contacts (reports, preprints, offprints, books, journals). Over the past eight years A. P. Ershov has received over 5,500 publications from abroad, valued at no fewer than 30,000 rubles in foreign currency. Most of the materials A. P. Ershov has received have come into the USSR in only a few copies or not at all. During the same period these materials have been lent out to over 600 scientific associates, including those from other cities, a total of around 20,000 times. $^{30}$

In the 1970s, when Ershov began to publicly develop his ideas about the human and social significance of the exponentially increasing significance and distribution of information, he was not relying on vague futurological projections. His participation in global computer science gave him direct experience of a global infosphere realized in material terms.

It was not, however, the elite and specialized scientific culture of Soviet or international programmers that provided Ershov with his most direct point of reference. Under the umbrella of cybernetics, competing visions of the social implications of computing technology had been debated in

27 EA f. 124, p. 147, Ershov to Carr, 7 December 1961.

28 EA f. 124, p. 33, Ershov to Peter Naur, 1 August 1962.

29 EA f. 57 , pp. 3-61.

30 EA f. 322, p. 144. 
the Soviet Union since the late 1940s. Slava Gerovitch's From Newspeak to Cyberspeak has provided an exceptionally successful treatment of these debates. Gerovitch traces the emergence of cybernetics in the Soviet Union to the late Stalin period, when it was officially condemned and persecuted as a malignant foreign import. As Gerovitch shows, Soviet cybernetics began as a countercultural movement that aimed to give a common language to the sciences in opposition to the increasingly meaningless and malleable "Newspeak" of dialectical materialism. In the 1950s, cybernetics-as the visiting Americans had noticed-exploded into public consciousness. In the pages of the popular as well as the scientific press, the new science raised a number of burning questions: could computers think, and what did this mean for human beings? How could computers and cybernetics be harnessed to solve scientific and technical problems? Most important, could the largescale introduction of computers into the Soviet planned economy, combined with cybernetic analysis of social feedback processes, hold the key to building a flourishing communist society? ${ }^{31}$

The Soviet leadership responded to the challenge of cybernetics with enthusiasm. After a determined push by Admiral Aksel' Berg, one of its earliest official supporters, cybernetics was assigned a key role in the 1961 Communist Party Program. The authorities promoted far-reaching plans to set up multiple levels of computer-based ASUs (Automated Control Systems) throughout the economy, starting with individual enterprises. The projector rather projects, since multiple ministries began implementing their own networks-failed over and over again for several decades, in large part due to the resulting fragmentation. ${ }^{32}$ Meanwhile, the official stamp of approval given to cybernetics as an umbrella science meant that, already by the early 1960 s, it was seen as an all-purpose tool for total, computerized, "scientific" economic and social control; as its institutional significance grew, its scientific and practical effectiveness shrank, and the result was an ideological "CyberNewspeak" that replicated all the faults of its Stalin-era predecessor. ${ }^{33}$

State recognition eventually introduced a duality into Soviet thinking about cybernetics. From the point of view of the Academy of Sciences and the scientific community in general, it was still a scientific discipline with

31 Slava Gerovitch, From Neuspeak to Cyberspeak: A History of Soviet Cybernetics (Cambridge, MA: MIT Press, 2002); Graham, Science, Philosophy, and Human Behavior in the Soviet Union, 266-92 . Francis Spufford's unusual "non-fiction novel" Red Plenty (London: Faber and Faber, 2010) offers an especially compelling treatment of this question.

32 Gerovitch, "InterNyet: Why the Soviet Union did not build a Nationwide Computer Network," History and Technology 24, 4 (2008): 335-50.

33 Gerovitch, From Newspeak to Cyberspeak, 253-92. 
a relatively concrete, albeit expanded, portfolio: the generalized analysis of feedback processes, primarily using mathematical and computational methods. Yet it also provided the Brezhnev era with a language with which to conceptualize the stability and authority of sociopolitical structures, without sacrificing the emphasis on scientific and technical progress that continued to be a hallmark of official rhetoric.

As Gerovitch has pointed out, the work of the Soviet philosopher (and, after 1976, Pravda editor) V. G. Afanas'ev on "social information" provides an especially clear illustration of this theme. Information had been one of the primary components of cybernetics from the beginning, since the science's basic premise is that systems adjust their functioning on the basis of feedback. A unit of information became defined in this context as a "single decision between equally probable alternatives," and information as such was contrasted to entropy. With the application of cybernetic analysis to society, however, precise definitions became more difficult. Wiener proposed a model of "group" or "communal" information based on observations and behavioral adjustments made by the members of a group, linking it to the homeostasis of small, natural communities. ${ }^{34}$ In 1975, Afanas'ev published Social Information and the Control of Society, where he defined "social information" as "information circulating in society and used in the control of social processes." (The word "control" [upravlenie] was key for Soviet cyberneticians because of the way it conflated a specialized cybernetic term with a word often emphasized by Lenin.) Unlike Wiener's group information, social information was held to "carry the deep trace of class, national, and other relations, the trace of the needs, interests, and psychological traits of the collective." 35 The 1970s Soviet adaptation of Wiener's model involved an even more explicit merger of normative and descriptive language.

This was why the "central place in the system of social information" was occupied by "political information," which encompassed political relationships, organizations, and ideology (whether bourgeois or Marxist-Leninist). The political-information model envisioned a core-periphery relationship in which information about the masses' "moral-political status, interests, needs, and mood" flowed inward to the Party, while knowledge, guidance, and propaganda flowed back outward. ${ }^{36}$ In an earlier essay, Afanas' ev had declared that one of the main achievements of cybernetics was its discovery that "control

34 Wiener, Cybernetics, 11, 155-64.

35 Gerovitch, From Newspeak to CyberSpeak, 254-87; V. G. Afanas'ev, Sotsial'naia informatsiia i upravlenie obshchestvom (Moscow: Politizdat, 1975), 39.

36 Afanas'ev, Sotsial'naia informatsiia, 354-98. 
has an essentially anti-entropic nature, and its calling is to counteract external and internal factors disturbing [vozmushchaiushchie] to the system." ${ }^{37}$

"Social information," in other words, was meant to provide a cybernetic theory of management for developed socialism - management in the businessschool sense of the term. In recognition of the broad applicability of his model, Afanas'ev was invited to serve as a management consultant for IBM after the publication of Social Information, an offer he refused in order to assume the editorship of Pravda. ${ }^{38}$ On a practical level, one of the most significant tasks of cybernetic management was to tame the "information explosion" and efficiently cope with the enormous and increasing amount of bureaucratic paperwork, ultimately in order to convert "reference information" into "command information." Afanas'ev emphasized the significance of ASUs, document standardization, and statistical computing. Although computers would be indispensable for all these tasks, they would be strictly ancillary. The central place would still be reserved for the human bureaucrat, whom he made no mention of diminishing or displacing. Instead, he stressed the social importance and value of "information-processing labor," arguing that "in the final analysis all work with information is oriented toward the person in authority or the state organization [organ] that makes the decision." "Control," he wrote, "is a uniquely elevated form of [specifically] human creativity." 39

Well before he had begun to write about social information, however, Afanas' ev was already thinking about the relationship between human beings and computers. In an apparently unpublished 1967 essay on "The 'HumanMachine' System in Automated Production," he attempted to untangle the knot tying "social man" to his tools of production in an environment where the tools themselves would be controlled by machines. ${ }^{40}$ For Afanas'ev, the relationship between the worker and the computer was fundamentally agonistic: computers were constantly running up against the limits of the people assigned to them, causing either "information hunger" or "information overload." "The operator's activity," he wrote, "does not always correspond to the demands of the optimal flow of the process, its rapidity and precision. Between 20 and 58 percent of control-system failures are connected with mistakes in the work of the human operator." To compensate for these defects, cybernetic devices were required to relieve the human being of as much

37 Tsentral'nyi muzei-arkhiv lichnykh sobranii, Moscow (hereafter TsMAMLS) f. 2 (V. G. Afanas'ev), op. 1, d. 45, 11. 31-39.

${ }^{38}$ Ibid., d. 79, 11. 36-38.

39 Afanas'ev, Chelovek v upravlenii obshchestvom (Moscow: Politizdat, 1977), 130-37; Afanas'ev, Sotsial'naia informatsiia, esp. 258-92, 306-17.

${ }^{40}$ TsMAMLS f. 2, op. 1, d. 44, 1. 1. This essay does not appear in Afanas'ev's voluminous autobibliography (d. 79), so it almost certainly remained in draft form. 
responsibility for their operation as possible. Humans, meanwhile, were to undergo "comprehensive preparation for labor in conditions of scientifictechnological revolution and automated production," inculcating "maximum flexibility, stamina, exceptional reaction speed, 'interference immunity,' the ability to rapidly change focus." As in the case of the creative bureaucrat, however, Afanas' ev's argument here attempted to stake out a vague privileged ground of "creativity" and "intuition" that would not be susceptible to displacement by cybernetic machinery. ${ }^{41}$

Afanas'ev's essay amounted to a rudimentary sketch of a labor-forcewide program of computer education. Its basic assumptions, however, were fundamentally at odds with Ershov's. Human-computer interaction, in the social-cybernetic view, could be envisioned only in rigidly instrumental terms; human beings needed to be "adapted" physically and psychologically to hostile machines; and, most important, human intuition and creativity was always defined in opposition to the encroaching capabilities of computers, so that the two could never overlap. Remarkably, Afanas'ev articulated almost the same position-occasionally reusing identical arguments word-forword, with minor vocabulary adjustments - in an article written in 1991, concluding with the line "Unto technology the things that are technological, unto man the things that are human." ${ }^{2}$

It was against this background that Ershov's utopian ideas began to develop. Over the course of his career - and especially in the 1970s and 1980 s- he articulated an evolving vision of "informatics" (informatika), a term that he did not invent but to which he gave a broad and far-reaching interpretation. In a 1984 article, he traced the initial appearance of the word to the mid-1960s, when it was used either as a direct borrowing from the French term for "computer science" (informatique) or as a Latin-based neologism denoting the study of scientific information. But the large-scale diffusion and broad redefinition of the term, in his view, did not take place until the 1976 publication of the Russian translation, from the German, of F. L. Bauer's Informatik. Only then did it come to mean a "basic natural science dealing with processes of information transmission and processing." The article did not mention that Ershov had not only had a direct hand in getting Bauer's work into print but was also its official editor. ${ }^{43}$ By 1988, Ershov was chairing 41 Ibid., d. 44.

42 Afanas'ev, "Chelovek, komp'iuter, tvorchestvo," Sovetskaia pedagogika, no. 5 (1991): $50-56$.

43 EA f. 267, p. 166, A. P. Ershov, "O predmete informatiki," Vestnik AN SSSR, no. 2 (1984); f. 128, p. 319, Ershov to F. L. Bauer, 2 May 1973; f. 122, p. 400, Bauer to Ershov, 2 February 1977. See also Yu. Chiorny, "On Notion of Informatics in Works of Academician Ershov," in Trudy SORUCOM-2011, 341-49. Chiorny points out that it was through a willful 
the Council on Cybernetics while suggesting that informatics had "in a way taken over" the old field's functional domain-"but we are not attempting to change either the name of the Council on Cybernetics or the traditions of its first chairman, Aksel' Ivanovich Berg." ${ }^{44}$ Like cybernetics, informatics had both a technical and a speculative meaning; even Afanas'ev could describe himself as an informaticist in the former sense, though his refusal to sign on to a program like Ershov's meant he could not be one in the latter.

Informatics in the speculative sense was defined, above all, as the domain of a specific kind of person. Already in the late 1960s and early 1970s, Ershov had begun to draw attention to the need to train an increasing number of programmers if officially declared plans to cyberneticize the economy and close the systems gap were ever to succeed. In 1970, he highlighted the urgency of the issue in an article in Pravda. ${ }^{45}$ But programming education was much more than a public policy problem. It implied and required the creation of individuals with particular kinds of personalities, capabilities, and worldviews. In a talk titled "Where Do People Who Can Produce Reliable Software Come From?" presented at a conference in Los Angeles in 1975, Ershov enumerated a number of qualities, all of which programmers needed to possess "in their extreme manifestation." They included the "ability to seize the essence of the matter," as well as logical thinking, patience, discipline, and an ability to plan one's activity. The education of such people demanded a seven- to eight-year course of training that would unite high-level mathematics with "professional perfection" and an "engineer's orientation toward productive results." 46 This complex of ideal qualities was profoundly influenced by Ershov's experiences in Akademgorodok and as an international computer scientist, spheres in which these attributes were valued above all else. Soon Ershov would come to see all these qualities as facets of algorithmic thinking.

If the coming age was to be dominated by algorithmic machines, programmers, because of their mastery of algorithmic thinking, would come to occupy a uniquely central place in society. Ershov developed this idea most fully in a keynote address to the Spring Joint Computer Conference in Atlantic City in May 1972. Titled "Aesthetics and the Human Factor in Programing,"

misinterpretation of the French and German terms that Ershov brought two distinct forms of "informatics" into being in the Soviet Union: one focused on information strictly speaking, the other on computing. These correspond in a general sense to the two categories I point to here, although "computing informatics" does not capture the utopian overtones of his usage.

44 EA f. 606, p. 345, Andrei Illarionov, "Gost' 13-i stranitsy: Akademik Andrei Ershov," Nedelia, no. 38 (1988).

45 EA f. 342, pp. 272-85, A. P. Ershov, "EVM-kompleks problem," Pravda, 9 April 1970; f. 350 , pp. $1-2$; f. 347 , pp. 344-87.

46 EA f. 550, pp. 25-31. 
it was reprinted in at least five American publications and subsequently cited by Frederick Brooks, Jr., in his legendary book The Mythical Man-Month. ${ }^{47}$ The speech suggests that programming is "the most humanly difficult of all professions involving numbers of men," not only because "programers constitute the first large group of men whose work brings them to those limits of human knowledge which are marked by algorithmically unsolvable problems and which touch upon deeply secret aspects of the human brain," but also because the programmer "must join the accuracy of a bank clerk with the acumen of a scout, and to these add the powers of fantasy of an author of detective stories and the sober practicality of a businessman." ${ }^{48}$ The programmer's privileged status affords him "both intellectual and vivid emotional satisfaction" based on the "rich, deep, and novel esthetic principles" of his craft. After exploring the sources of this satisfaction, Ershov delivers the crowning analogy:

The progressive expansion of software is, it seems to me, comparable in many ways to the phenomena set in motion by the invention of printing. The accumulation of books, each one embodying its author's view of the external world, broadened a social process of understanding. In the same way, programs and data banks accumulate informational and operational models of the world.... To be a good programer today is as much a privilege as it was to be a literate man in the 16 th century. ${ }^{49}$

Ershov was not a crude technological determinist. His ideal of the programmer, as he saw it in the mid-1970s, required social developmentsdramatically expanding horizons of information access and distribution-to go hand-in-hand with technological ones. His ideal was no longer simply professional: it was founded on a more fundamental claim about the programmer's citizenship in a new kind of society. As he concluded his speech, Ershov referenced the educational ideas of Marvin Minsky and Seymour Papert and asked if "the highest esthetic ideal of our profession" was not "to make the art of programing public property, and thereby to submerge our aesthetic exclusiveness within a mature mankind." Although he sketched out an analogy to "general literacy," however, his proposals remained unspecific. ${ }^{50}$

${ }^{47}$ Kraineva, "Nauchnaia biografiia," 254; Frederick P. Brooks, Jr., The Mythical Man-Month (Reading, MA: Addison-Wesley, 1975), 179 n. 1.

48 A. P. Ershov, "Aesthetics and the Human Factor in Programing," Jurimetrics Journal 13, 3 (1973): 142-49. I have used the spelling "programing, programer" in direct quotations from this version of the speech, but Ershov himself seems to have used the standard spelling.

49 Ershov, "Aesthetics and the Human Factor," 146.

50 Ibid., 148. 
Ershov's ideas about the relationship between general education and computer technology were, in fact, closely shaped by contemporary Western developments, which he was able to learn about through his network of foreign contacts. Ershov's general preoccupation with human-machine interaction led him to correspond with Edward Feigenbaum and John McCarthy about new technologies for computer-aided instruction being developed in the United States in the mid-1960s. ${ }^{51}$ Among the many titles Ershov brought back from the United States with him in 1970 were descriptions of PLATO, a pathbreaking early attempt at an integrated, graphical computer system for education. By far the greatest influence, however, seems to have been exerted by Seymour Papert, an MIT professor whom he met during that trip. ${ }^{52}$ Papert's ideas, which became broadly popular in the $1970 \mathrm{~s}$ and $1980 \mathrm{~s}$, focused on the computer's potential to develop untapped human abilities and "help people form new relationships with knowledge that cut across the traditional lines separating humanities from sciences and knowledge of the self from both of these." He opposed the traditional model of computeraided instruction, in which "the computer programs the child," to one in which "the child programs the computer." Children, in Papert's view, were to be given the opportunity to experiment independently with simple programming languages like LOGO (which he invented in 1967) to accomplish limited tasks in a restricted environment, a practice that would help them develop algorithmic thinking and an openness to mathematics. ${ }^{53}$

While Papert's thinking proved vital for Ershov, perhaps even more important was the emergence of the microprocessor-based personal computer (PC) in the second half of the 1970s. Hardly any PCs were produced in the Soviet Union before the end of the 1980s, but Ershov was nonetheless aware of their epochal significance. "The concept of the personal computer," Ershov wrote in 1983, "broke up many of the established directions of computer technology and programming, revealed a number of growing contradictions in the development of computing, and placed new characters on the stage.... The PC, it seems, is returning to the programming and usage of computers the integrity that ... was carefully being destroyed by

\footnotetext{
51 See, e.g., EA f. 126, pp. 59-63, Ershov to McCarthy, 28 June 1966; and f. 133, pp. 17475, Feigenbaum to Ershov, 22 December 1965.

52 EA f. 57, p. 13. (Papert wore Ershov's badge during a 1966 conference, but they did not know each other at the time. See EA f. 132, pp. 147-53, McCarthy to Ershov, 10 May 1966.) 53 Seymour Papert, Mindstorms: Children, Computers, and Powerful Ideas (New York: Basic Books, 1980), 3-18. Italics in orig. For a classic account of the psychological effects of computers - and of Papert's ideas in particular - see Sherry Turkle, The Second Self: Computers and the Human Spirit (New York: Simon and Schuster, 1984).
} 
the grandees [korifei] of professional programming." 54 The personal computer was not only transforming programming by creating a whole new class of programmers whose principal client was themselves; it was also changing society by imposing new computer skill requirements and providing the means of addressing them. For instance, the large-scale use of microprocessorbased systems would enable the automatization and dramatic reduction of bureaucratic white-collar work. ${ }^{55}$ Specifically in the educational context, the personal computer held tremendous significance because it could both bring informational-computational power and visual displays directly to student desks and provide students with more developed, interactive "world models." 56

Personal computers led Ershov to recapitulate his analogy to the history of reading, moving the parallel forward into the age of mass literacy. Where before his story focused on the unique privileges available to the literate person-the programmer-at the dawn of the Gutenberg era, now he stressed the "interdependence of the development of book printing and the universal literacy it required." Like printed books, personal and embedded processors would serve to catalyze a mass public for whom universal education in programming would take the place of literacy. Not only would this lead to new modes of appreciating and using information; it would also give children an "active life position"-that is, the "ability to develop a program of action and follow it"-as well as "accelerate their intellectual ripening" by helping them develop algorithmic thinking and the capacity for reflection and abstraction. In short, the future of education as Ershov saw it would involve the training of everyone in those qualities that he had long considered necessary for an ideal programmer. The emergence of the personal computer would democratize the skills and qualities of this new intellectual elite. Like books, computers were the bearers of a transformative new "informational model of the external world." ${ }^{57}$ Over the course of the 1970s, Ershov had gone from making a narrowly technical claim about the training of programmers to an all-encompassing vision of the information age that was opposed, both substantively and rhetorically, to the language of control and discipline that dominated Soviet cybernetics.

Ershov's growing engagement with questions of significance to a broader public was in part the result of his increasing stature in the world of Soviet programming. In 1970, he was made a corresponding member of the

54 EA f. 209, pp. 322-36.

55 A. P. Ershov, "Dva oblika programmirovaniia," in Izbrannye trudy, 309-13; EA f. 498, pP. $329-42$.

56 EA f. 281, p. 9.

57 A. P. Ershov, "Programmirovanie-vtoraia gramotnost'," in Izbrannye trudy, 32-40. 
Academy of Sciences, and from this period on, he began to play an active role in editing computer-science journals, organizing union-wide conferences, and serving on government commissions. ${ }^{58}$ In 1979 , he published a pamphlet on "school informatics" with two of his colleagues. This framed the somewhat illdefined ideas of his Atlantic City speech in terms of the concrete actions and structures that needed to be put in place to informatize the Soviet educational system-a process envisioned as gradual and evolutionary. They included the development of an appropriate educational computer language along the lines of LOGO, as well as databases and hardware. New textbooks were also needed, because the existing ones failed to appreciate the significance of information processing and treated the computer as a glorified calculator. ${ }^{59}$ Meanwhile, Ershov began to write and publish articles about educational computing in the popular press, which were intended to demonstrate to the broader reader that programming instruction was a necessity, not a luxury. ${ }^{60}$

Although his efforts to promote an evolutionary model of school informatics gained the support of state and party authorities, by 1985 it was clear to Ershov that the "infiltrationist model," as he called it, had failed: "It turned out that this strategy was incapable of overcoming inertia and an inadequate level of social consciousness, as well as the subsequently revealed 'braking mechanism' of social development in general." A "frontal assault" was now needed. At any rate, in late 1984 (after Ershov had become a full member of the academy), the Ministry of Education, after considerable work on the part of Ershov and others, ordered that a course on "Foundations of Informatics and Computing Technology" be introduced in all ninth and tenth grade classes everywhere in the Soviet Union the very next school year. This was not enough, however: a "firm" and "abrupt" "political decision" was going to be necessary. Ershov appealed to the Politburo, which decreed an even more large-scale deployment of school informatics on 9 March 1985. Gorbachev himself wrote the mandate. ${ }^{61}$

58 Kraineva, "Nauchnaia biografiia," 97-164.

59 A. P. Ershov et al., eds., Shkol'naia informatika: Kontseptsii, sostoianie, perspektivy (Novosibirsk: Vychislitel'nyi tsentr Sibirskogo otdeleniia Rossiiskoi akademii nauk, 1979); EA f. 167 , pp. $156-83$.

60 EA f. 155, pp. 13-18, A. P. Ershov, "EVM v mire liudei," Sovetskaia kul'tura, 14 April 1985; f. 209, p. 25, Ershov, "Chelovek i komp' iuter," Izvestiia, 2 February 1984.

61 EA f. 280, pp. 21-34. The most comprehensive overview of the program, which situates the computer literacy program in the context of the more general 1980 s school reform effort as well as analogous projects in other countries, is Stephen T. Kerr, "Educational Reform and Technological Change: Computing Literacy in the Soviet Union," Comparative Education Review 35, 2 (1991): 222-54; see also Richard Judy and Jane Lommel, "The New Soviet Computer Literacy Campaign," Educational Communication and Technology 34, 2 (1986): $108-23$. 
Ershov offered his most comprehensive defense of his vision for the computer literacy program in the Kommunist article quoted at the beginning of this essay. "Informatization: From the Computer Literacy of Students to the Information Culture of Society" was published in 1988-the year of his death. In it, he argued that computerization was not only necessary if the USSR was to succeed in the 21st century but an eminently achievable goal. Although Ershov acknowledged the present limits to the growth of the information sector in the Soviet Union, he saw in it unlimited potential. Personal computers would dramatically reduce the need for bureaucrats and white-collar workers, thereby unlocking the power of private creative initiative and fostering the "democratization of the information structure of society"-a formula that suggested Ershov was adapting informatics to perestroika much as cybernetics had been adapted to developed socialism. But informatization entailed more than mere short-term social changes; it represented nothing less than a cognitive watershed for human civilization as a whole. Here lay the unique advantage of the Soviet system, for "even by virtue of its design, the socialist society has the ability to realize the social function of informatization gradually and harmoniously through its educational institutions." ${ }^{2}$ The computer literacy program, in Ershov's view, was both aligned with the goals of perestroika and fundamental for realizing his utopian vision.

The program launched on schedule, after a rapid crash course for teachers, using a provisional textbook authored by Ershov and his Novosibirsk colleagues. One of the major difficulties became apparent immediately: the Soviet Union simply lacked the numbers of personal computers required to make a nationwide effort reasonable. Although multiple ministriesincluding the Ministry of Radio Manufacturing, the Ministry of Electronic Manufacturing, and others-had submitted proposals for their hardware to be used, all had serious deficiencies and no ministry was capable of delivering computers in sufficient quantities. A considerable number of Yamaha machines were imported to compensate, but they were too expensive and their numbers were insufficient. ${ }^{63}$ Since even Moscow schools were undersupplied, and the situation in rural areas and in less developed republics was downright catastrophic, some alternative way of fulfilling the mandate had to be found.

In the vast majority of Soviet schools, the computer literacy course was taught without computers. Although Ershov himself always insisted on the importance of putting students into direct contact with PCs, this basic lack

62 A. P. Ershov, "Informatizatsiia: Ot komp'iuternoi gramotnosti uchashchikhsia k informatsionnoi kul'ture obshchestva," in Izbrannye trudy, 371-84.

63 Gosudarstvennyi arkhiv Rossiiskoi Federatsii (GARF) f. R-9563 (Ministerstvo prosveshcheniia SSSR), op. 1, d. 4910. 
actually seemed to dovetail with a key aspect of his educational program: training in algorithmic thinking, the key skill of citizens in the age of informatization. In addition to a large body of material on the social and economic significance of computers, the "machineless variant" implied that students could be taught algorithm construction (using a form of notation similar to computer code) without ever seeing a screen. Predictably enough, student interest in the course declined by 80 percent once it was discovered that no computers or even real computer languages were actually involvedalthough students at schools with computer labs also lost interest. Part of the problem may have been that provisional sanitary (i.e., ergonomic) guidelines established by the Ministry of Health limited schoolchildren to 20 minutes of computer time a week. ${ }^{64}$

Even more seriously for Ershov's vision, the Ministry of Education and the commission charged with implementing the informatics course (headed by Evgenii Velikhov) took aim directly at the cornerstone of the whole concept. In December 1986, it offered three basic criticisms of Ershov's provisional textbook. First, it was "overloaded with material unnecessary for a general education school and more appropriate for pre-professional programming training." Second, it failed to emphasize interdisciplinary connections beyond physics and mathematics. Finally, it "fails to sufficiently clarify the concept of 'information'-one of the key concepts of the new subject." In contrast, the commission proposed that the course focus on skills that would be directly useful to students in a practical context, and specifically not train them to be programmers. "It should be kept in mind," one of its theses suggested, "that the majority of secondary-school graduates will have contact with computers only in an end-user capacity, if at all, while the tendency is for computers to become easier to use, thus requiring fewer programming skills." ${ }^{65}$

Ershov registered his objections to this evaluation in an article in Uchitel'skaia gazeta two months later. Information could not be defined through an "isolated piece of reasoning"; it had to "interpenetrate the whole fabric of the textbook." For their part, "algorithmization and programming ... make up the lion's share of the intellectual effort involved in solving problems on a computer. The structure of this process, its knowledge and skill-building role, cannot be replaced by any 'pushbutton' application of a readymade program-product.... The course cannot be deprived of this creative core, which serves as an axis for all the other components of information culture." ${ }^{66}$ Without a rigorous, quasi-professional, and universal course of programming

64 Ibid., op. 2, d. 734, 11. 4-6; op. 1, d. 5483, 1. 24.

65 Ibid., op. 2, d. 734, 11. 1-7.

66 A. P. Ershov, "Prosto-'Informatika," Uchitel'skaia gazeta, 16 February 1987. 
training, the information age he imagined would be left without an active citizenry.

Other criticisms were both more direct and more severe. One review of Ershov's text expressed incredulity that he could have been responsible for such a poorly organized and undeveloped product and suggested that he had never actually read it. ${ }^{67}$ In another, the prominent computer scientist S. S. Lavrov claimed that "[o]nly a short time ago, based on my 30 years of experience developing computer programs ... I would have suggested a [computer literacy] program project similar in structure to that developed by Academician A. P. Ershov." But new trends in the use of computers, centered on the usage of readymade programs by masses of office workers, were rendering the universal teaching of programming and algorithms obsolete. $^{68}$ I. I. Logvinov agreed with Lavrov and challenged the premise that Ershov's course structure could ever inculcate algorithmic thinking in the first place. "The basic psychological structures that characterize the general mental development of a person complete their formation by the age of 15," he wrote. "Any, even the most progressive, form of reinforcement and establishment of skills and habits demands a certain amount of time, which cannot be arbitrarily reduced." Given the amount of material packed into the course, and its often scattershot presentation, his prognosis was not optimistic - as the unimpressive classroom results soon bore out. ${ }^{69}$

In short, Ershov demanded too much of his students. His ideas, democratic and utopian though they were, were unable to coexist with a world of mass computing in which elite scientific culture no longer had the aspirational appeal it once did. Combined with the lack of computers, Ershov's narrowly algorithmic and professional horizons consigned the educational reform to irrelevance. The 1988 revision of the textbook halved the algorithm section, gave narrowly encyclopedic definitions of "information," and removed most of the advanced material. ${ }^{70}$ Ershov died on 8 December of that year; although he left no detailed attempt to take stock of the disaster, it was clear that mass computer literacy, as he had once envisioned it, was not a going concern.

The course was not the only component of the informatics campaign, however. In fact, a reviewer of a text for an "in-depth" version of the textbook had observed bluntly that no attempt at in-depth informatics teaching could succeed in a formal classroom setting: "It is pointless for the simple reason that teachers who have studied all the included sections in depth and are capable

\footnotetext{
67 GARF f. R-9563, op. 2, d. 735, 1l. 44-48.

68 Ibid., d. 783, 11. 17-19.

69 Ibid., op. 1, d. 5483, 11. 19-25.

70 Ibid., op. 2, d. 796, 1. 20.
} 
of translating them to the level of schoolchildren do not exist.... Talented and curious schoolchildren will find an opportunity to satisfy their ambitions through the network of computer clubs, pioneer palaces, extracurricular clubs, [etc.]."71 In fact, a major conference about the computer literacy campaign, held in April 1986, recommended that informal leisure spaces such as pioneer palaces, as well as popular-science publications, be leveraged on a broad scale to promote extracurricular informatics instruction. Such initiatives had already been implemented from the beginning of the campaign ${ }^{72}$

One publication enrolled in this extracurricular push was the Soviet Union's leading popular science magazine, Nauka i zhizn'. In June 1985, it announced a new section, "The School for Beginning Programmers." In a series of several dozen lessons, it would teach computer enthusiasts among the magazine's readership to program, starting with the basics; other new sections would provide them with a forum to send in letters, submit humorous computing-related stories, and exchange programming tips. Unlike the formal course, the magazine series did not limit itself to computers: in an attempt to reach the broadest possible audience, it focused initially on the widely available Elektronika-brand programmable calculators. ${ }^{73}$ The magazine Kvant, in which Ershov had begun to publish articles on programming in 1979, later motivated this choice specifically in relation to computerliteracy education: "Niklaus Wirth ... believes that educating all children in computer literacy up to the level of highly qualified programmers would be an unrealistic and short-sighted goal. But exposing as many children as possible to the possibilities of computers and programs is necessary, and the earlier the better. We would only add that the cheaper, more widely available, simple, and safe the devices are, the more reasonable [this goal] is." ${ }^{4}$

Although these lessons may have had low technological barriers for entry, this did not mean the subject matter was dumbed down. The practice problems often involved advanced mathematical concepts, and the emphasis was on exploiting the machine's limited capabilities to produce unexpected results. Many of the suggestions required modifying the hardware: for instance, rewiring the circuit board with a soldering iron. Other articles introduced readers to technological innovations created overseas and discussed the details

71 Ibid., d. 783, 11. 122-23.

72 Ibid., op. 1, d. 5296.

73 G. Slavin, "Shkola nachinaiushchego programmista," Nauka i zhizn', no. 6 (1985): 33-43.

74 V. Tarasenko, "Algoritmika prostoty," Kvant, no. 8 (1991): 74. Wirth, who taught in Switzerland and California, was the designer of Pascal and other important programming languages. 
of government plans for computer manufacturing. ${ }^{75}$ Later, Kvant invited its readers to create their own versions of Tetris by working around the severe limitations of programmable calculators. ${ }^{76}$

In December 1987, Nauka i zhizn', as part of an attempt to engage its readers in dialogue, published a letter from a reader that tried to make sense of the section's audience of amateurs. "Computer sections in popular-scientific magazines are multiplying like mushrooms after the rain.... Yet the common feature of all these publications is their total lack of an authorial stance. It is impossible to tell to whom this or that bit of material is being addressed, it's unclear what the author wants from his addressee and why." The author divided readers into four groups: amateur programmers, potential computer users, hobbyists- "who need to play with some kind of object to relax"-and people who read anything and everything. (They asked pointed questions, including "Who is playing the leading role in the current comedy with the school computers?"- a reference to the struggles of Ershov's computer literacy initiative.) Kvant, meanwhile, trumpeted the fact that it was read by everyone "from fifth-graders to pensioners," and one issue was read on average by five different people. It saw itself specifically as cultivating the ability of readers to transition "from an informally formulated problem to an algorithm." The tenacity of the computer sections and the proliferation of the genre all over the popular press testifies to the emergence in the Soviet Union of a nascent culture of computer hobbyists, accustomed to algorithmic thinking as well as free-range experimentation. Unlike school informatics, they seem to have fulfilled at least something of the promise Ershov envisioned for his educational project, though they would never measure up to the standards he had once set.

The irony of Ershov's vision, therefore, was that a set of ideals and expectations he originally developed within the narrow context of professional scientific elites ended up partially succeeding only among a public of amateurs, most of whom did not even own the personal computers Ershov saw as a sine qua non. As a blueprint for generalized, state-organized social transformation, his project was a dramatic failure; and the information age was now definitively seen in terms of ordinary people using, rather than programming, computers. ${ }^{78}$

\footnotetext{
75 V. Kudriavtsev, "V dvukh rezhimakh," Nauka i zhizn', no. 6 (1989): 105; "Personal' nyi komp' iuter: Chto, gde, kogda?" Nauka i zhizn', no. 12 (1987): 18-24. This kind of amateur technological culture had a long ancestry in the Soviet Union. See Stephen Lovell, "How Russia Learned to Listen: Radio and the Making of Soviet Culture," Kritika 12, 3 (2011): 591-615.

76 A. Kotova, "Vokrug 'Tetrisa," Kvant, no. 12 (1992): 49-51.

77 A. N. Vilenkin, "Kto i kak chitaet Kvant," Kvant, no. 11 (1988): 89.

78 See, e.g, A. Silin, "Vek informatiki," Nauka i zhizn', no. 2 (1989): 28-33.
} 
Yet at the individual level, Ershov's ideas about the cognitive and social implications of mass programming still left an imprint on Soviet and postSoviet computer culture. It is tempting, in fact, to suggest that the hackers and malware-creators for whom the Russian computing scene is known today are offshoots of late Soviet amateur computer culture: the first internationally known Russian computer hacker, Vladimir Levin, who stole over $\$ 12$ million from Citibank in 1994, was one of these self-taught hobbyists. ${ }^{79}$

In short, the information society that emerged in the 1990 s looked nothing like the "informatized" USSR Ershov had envisioned by the time of his death, even if personal computing proved to be every bit as transformative as he had imagined. Yet to see this in terms of prescience or lack thereof would be to miss the point. Ershov's vision of an infosphere dominated by liberated users with the algorithmic minds of professionals was the product not of well-informed forecasting but of an ideology shaped against the background of the Khrushchev-era boom in interest and investment in science whose fruits included Akademgorodok as well as official cybernetics. It had little to say about the world of actually existing computing, no matter how closely it was tied in with official policies on informatization. For all the talk of "accelerating progress," then, Ershov and the scientific-technical vision of the early perestroika years was looking backward, not forward. Caught up with responding to the challenges of the 1970 s, it proved ill-adapted to the more disruptive realities of the 1990s. Reconciling the information economy with the urgent demands of reform would not be so straightforward a task.

\author{
Dept. of History \\ Robinson Hall \\ Harvard University \\ 35 Quincy St. \\ Cambridge, MA 02138 USA \\ afinogen@fas.harvard.edu
}

79 Ogonek, 8 February $1999,40-47$. 